\title{
Homeobox Protein Hox-A1
}

National Cancer Institute

\section{Source}

National Cancer Institute. Homeobox Protein Hox-A1. NCI Thesaurus. Code C115066.

Homeobox protein Hox-A1 (335 aa, $237 \mathrm{kDa}$ ) is encoded by the human HOXA1 gene.

This protein plays a role in embryonic anterior-posterior pattern formation. 